\title{
DE LA UTOPÍA A LA RECONCILIACIÓN EN LAS ÚLTIMAS NOVELAS DE MARIO VARGAS LLOSA
}

\author{
Efraín Kristal
}

En este trabajo se sostiene que las últimas cuatro novelas de Vargas Llosa corresponden a un nuevo período de su trayectoria literaria. No son como sus primeras novelas, cuando había sido un defensor de causas revolucionarias, expresiones de un mundo social irredimible. Tampoco son exploraciones literarias de las consecuencias del fanatismo, o de personajes que tratan de conciliar su necesidad de transgredir con la vida gregaria, como sus novelas de los años ochenta. En este último período — señala Efraín Kristal- Vargas Llosa ha perdido el optimismo que lo caracterizaba y parece dar a entender que el mal en la humanidad es irradicable, pero esa actitud más pesimista lo ha llevado también a tratar el tema de la reconciliación. Vargas Llosa sigue interesado en el tema del fanatismo, pero ha cambiado de enfoque: se interesa ahora en las causas y las razones que

Efraín Kristal. Catedrático y director del Departamento de Literatura Comparada de la Universidad de California, Los Angeles (UCLA). Es autor de Temptation of the Word: The Novels of Mario Vargas Llosa e Invisible Work: Borges and Translation. Ha editado The Cambridge Companion to the Latin American Novel, y con otros tres colegas editó asimismo The Blackwell Encyclopedia of the Novel. Con John King, de la Universidad de Warwick, está editando The Cambridge Companion to Mario Vargas Llosa cuya publicación está prevista para febrero del 2012. Kristal@ucla.edu. 
riñeron a sus personajes con el mundo que les tocó vivir. En la nueva época las novelas de Vargas Llosa implican una apertura hacia el tema del amor, pero también hacia el tema de la resignación; y ha logrado elaborar un nuevo procedimiento literario mediante el cual su prosa narrativa puede leerse simultáneamente en un registro realista y en un registro fantasioso.

$\mathrm{D}$ urante su larga carrera literaria, Mario Vargas Llosa ha tenido una preocupación central: la propuesta de que nuestras esperanzas y deseos son inevitablemente más poderosos que nuestra capacidad para satisfacerlos. Algunos de sus personajes más memorables sienten - a veces de manera intuitiva y otras de manera visceral - lo que Vargas Llosa ha afirmado en sus ensayos literarios más importantes: que algo está mal con la sociedad en la que les tocó vivir; que los medios que disponemos para enfrentarnos con las dificultades de la vida son insuficientes; que hay fuerzas irracionales, destructoras - dentro y fuera de nosotros- que nunca podremos domar ni controlar.

En el mundo literario de Vargas Llosa la infelicidad y el sufrimiento son tan ubicuos como las dos respuestas con las cuales sus personajes hacen lo que pueden para sobreponerse a sus malestares: la rebelión y la fantasía. En la década de 1960 cuando Vargas Llosa era un socialista comprometido, estaba convencido de que la insatisfacción humana provenía directamente de los sistemas políticos y económicos que la acción revolucionaria podría desmantelar; y en sus primeras novelas Vargas Llosa deslumbró al mundo literario por la maestría literaria con la cual logró representar los efectos nefastos de una sociedad corrupta.

En la década de 1980 Vargas Llosa abandonó sus convicciones socialistas. Dejó de insistir en que la violencia debería ser una herramienta legítima para llevar a cabo el cambio político que eliminaría las causas fundamentales de la infelicidad. Más aun, empezó a insistir en que los orígenes de la inestabilidad social y la violencia política se encontraban en las mismas ilusiones que él mismo había tenido en su época socialista: que las utopías sociales eran posibles. En la década de los 80 , sus novelas trataron la fragilidad de las sociedades cuya estabilidad estaba comprometida por fanáticos, oportunistas políticos, o idealistas 
bien intencionados para los cuales la violencia es el medio más atractivo para cambiar el mundo. Su obra maestra de este período, La guerra del fin del mundo, se puede leer como una investigación literaria sobre la idealización de la violencia ya sea con los presentimientos apocalípticos de los líderes religiosos, el fervor patriótico de los militares profesionales, o las abstracciones de los intelectuales que no logran apreciar la guerra por lo que es: la más devastadora de todas las experiencias colectivas.

En las décadas de 1960 y 1980 Vargas Llosa sostuvo convicciones políticas sumamente distintas y hasta opuestas, pero su actitud hacia la actividad política era la de un optimista convencido de que los problemas sociales de Latinoamérica tenían claras soluciones. Estaba convencido, asimismo, de que la literatura podría contribuir a mejorar la sociedad. En su época socialista estaba convencido de que la literatura denunciaría las injusticias de una sociedad corrupta, y cuando se dio su giro hacia la defensa del mercado libre, afirmó que la literatura podría refrenar nuestra propensión a la violencia. Especulaba, entonces, que la imaginación literaria podría mezclar elementos de las realidades de nuestras vidas imperfectas con nuestras pulsiones más irracionales para darnos la ilusión de una plenitud que jamás se podría realizar en el mundo real.

En la década de 1990, una visión cada vez más pesimista ha cundido por todos sus escritos - tanto en sus ficciones como en sus ensayos-, es decir un sentimiento de creciente resignación según el cual todos nuestros esfuerzos para sobrellevar nuestros sentimientos de insatisfacción con nuestras vidas están destinados a la decepción. Vargas Llosa ha dejado de expresar sus convicciones; pero sus observaciones ya no son las de quien milita por un programa político sino más bien las de un moralista indignado con las injusticias de su mundo, pero resignado con las imperfecciones de la humanidad, y con la propuesta de que el mal nunca se podrá erradicar del todo. Su pesimismo se ha empezado también a manifestar en sus novelas, a partir de Lituma en los Andes (1993) cuando un personaje no puede explicar por qué participó en una masacre en el corazón de los Andes, pero es también lo que expresa un personaje de El sueño del celta:

La maldad la llevamos en el alma, mi amigo. En los países europeos está más disimulada, sólo se manifiesta a plena luz 
cuando hay una guerra, una revolución, un motín. Necesita pretextos para hacerse pública y colectiva. En la Amazonía, en cambio puede mostrarse a cara descubierta y perpetrar las peores monstruosidades sin las justificaciones del patriotismo o la religión. La maldad que nos emponzoña está en todas partes donde hay seres humanos, con las raíces bien hundidas en nuestros corazones ${ }^{1}$.

El creciente pesimismo de Vargas Llosa le ha quitado el fuego a sus pronunciamientos políticos dando espacio a una actitud menos polémica y más conciliatoria en sus ensayos, una actitud de mayor conmiseración con quienes Vargas Llosa tuvo sus más vivas polémicas en épocas anteriores. En su ensayo acerca de la confesión de Günter Grass sobre su breve adhesión al nazismo, Vargas Llosa se expresa con un tono que difiere considerablemente del período durante el cual participó en ácidas polémicas con escritores progresistas como Mario Benedetti y el propio Grass.

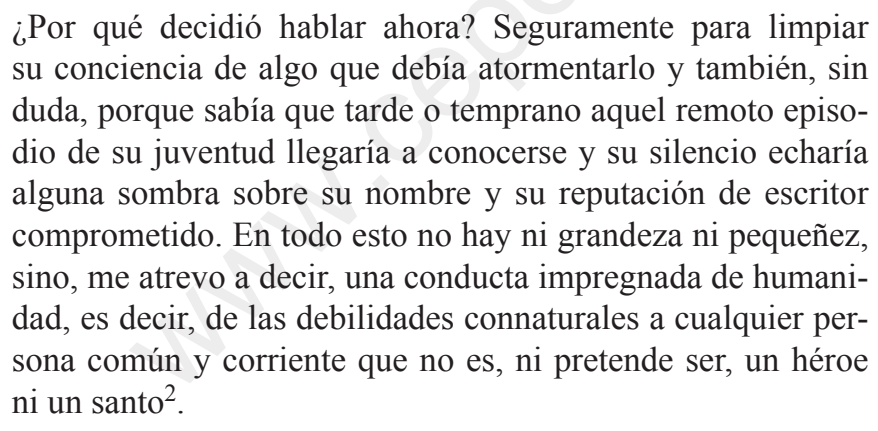

El ensayo de Vargas Llosa concluye con la afirmación sobre las pretensiones que Grass y el propio Vargas Llosa habían tenido sobre la función social del escritor:

Mejor aceptar que los escritores, por el simple hecho de serlo, no tienen que ser ni más lúcidos ni más puros ni más nobles que cualquiera de los otros bípedos, esos que viven en el anonimato y jamás llegan a los titulares de los periódicos. Tal vez sea ésa la razón por la que, con motivo de la revelación

\footnotetext{
${ }^{1}$ Mario Vargas Llosa, El sueño del celta, 2010, p. 298.

2 Mario Vargas Llosa, "Günter Grass en la picota", El País, agosto 27, 2006.
} 
de su paso fugaz por la Waffen-SS cuando era un adolescente, haya sido llevado Günter Grass a la picota y tantos se encarnicen estos días con él. No es con él. Es contra esa idea del escritor que él ha tratado de encarnar, con desesperación, a lo largo de toda su vida: la del que opina y polemiza sobre todo, la del que quiere que la vida se amolde a los sueños y a las ideas como lo hacen las ficciones que fantasea, la del que cree que la del escritor es la más formidable de las funciones porque, además de entretener, también educa, enseña, guía, orienta y da lecciones. Ésa era otra ficción con la que nos hemos estado embelesando mucho tiempo, amigo Günter Grass. Pero ya se acabó.

El tono de los ensayos de Vargas Llosa en los que insiste en las limitaciones humanas corresponde a un cambio importante en su manera de presentar las imperfecciones de sus personajes literarios en sus novelas. El cambio es tan notable que se puede hablar de un tercer período en la trayectoria literaria de Vargas Llosa después de su período socialista y de su período liberal. Durante este nuevo período Vargas Llosa ha publicado cuatro novelas: La fiesta del Chivo (2000), El Paraíso en la otra esquina (2003), Travesuras de la niña mala (2006) y El sueño del celta (2010). Vargas Llosa ha dejado de creer en la acción revolucionaria, pero su voluntad de tratar la corrupción de un mundo imperfecto ha regresado con toda la fuerza con la que lo hizo en sus novelas de los años 60 . Ha regresado también la valoración de aquellos personajes - como su Flora Tristán en el Paraíso o Roger Casement en El sueño del celta - que reconocen las injusticias de las sociedades plagadas de abusos y estropicios ya sea para confrontarlos con sus rebeldías o escapándose a otros ambientes más soportables. En sus últimas novelas Vargas Llosa sigue tan interesado como nunca en aquellos personajes que están dispuestos a cambiar sus vidas en nombre de alguna utopía, pero su actitud hacia ellos ha cambiado: ya no se trata, como lo fue en las novelas de la década de 1980, de seres despreciables por los estropicios que causan, o grotescos por sus absurdas convicciones. Vargas Llosa empieza a tratar a sus fanáticos, incluso a sus personajes revolucionarios, con compasión, preocupación, y hasta melancolía; se empieza a interesar ya no en el efecto de sus acciones, sino más bien en los traumas y los sufrimientos que los enemistó con el mundo que les tocó vivir. 
También se ha dado un cambio con relación a sus personajes femeninos. Los personajes femeninos de Vargas Llosa habían sido, a grandes rasgos, ya sea las aliadas de sus compañeros, u objetos de sus deseos sexuales. Sus personajes femeninos más memorables de otras épocas, entre ellas Teresa de La ciudad y los perros, Lalita de La casa verde, o Jurema de La guerra del fin del mundo, se comportaban siguiendo el patrón de obediencia y sumisión, y sus relaciones románticas servían para realzar aspectos de los dramas de los protagonistas masculinos. El tipo femenino más recurrente de la ficción de Vargas Llosa había sido la mujer que responde con una sorprendente capacidad de recuperación, y hasta con una actitud de risueño optimismo, a las humillaciones y abusos que ha sufrido; pero mientras que entonces Vargas Llosa hacía hincapié en la vitalidad de sus personajes femeninos, en las últimas novelas ha reorientado su mirada hacia una exploración más realista y por ello más sombría y lúgubre con relación a esas mismas humillaciones. Ahora el tema del abuso sexual y de sus consecuencias en la vida de los individuos e incluso en las generaciones ocupa un lugar central en sus últimas novelas.

En La fiesta del Chivo la violación de su protagonista, Urania Cabral, llega a convertirse en la alegoría del ultraje sufrido por toda una nación a manos de un dictador. Ésta es probablemente la primera novela sobre un dictador latinoamericano que rastrea los procesos mediante los cuales un hombre fuerte tiene que envilecer la dignidad y el amor propio de sus colaboradores más cercanos para mantenerse en el poder; y una de las pocas novelas políticas latinoamericanas en las cuales la indignación ante los crímenes de un dictador se representa con los sentimientos de culpabilidad, de vergüenza, de mala conciencia tanto de las víctimas como de los que cometieron crímenes y vejaciones durante su régimen. Desde este punto de vista, el magnicidio de la novela por los antiguos colaboradores del dictador Trujillo es un acto de catarsis. Uno de los mensajes morales de la novela está en la novela misma cuando el narrador ingresa en la conciencia de un conspirador para tratar el tema del mal:

[E]se mal de tantos años, pensar una cosa y hacer a diario algo que la contradecía, lo que lo llevó, siempre en el secreto de su mente, a sentenciar a muerta a Trujillo, a convencerse de que, mientras viviera, él y muchísimos dominicanos estarían condenados a esa horrible desazón y desagrado de sí 
mismos, a mentirse a cada instante y engañar a todos, a ser dos en uno, una mentira pública y una verdad privada prohibida de expresarse ${ }^{3}$.

Los conspiradores de la novela no se oponen al dictador Trujillo por razones ideológicas. No son militantes de un partido o movimiento político (y no podrían serlo porque los servicios secretos de Trujillo han logrado reprimir toda oposición política a la dictadura). La mayoría de los conspiradores son hombres adultos que estuvieron alguna vez asociados al régimen de Trujillo. Representan un panorama de la sociedad dominicana: militares, beatos, hombres de negocios, inmigrantes, etc. Los une el sentimiento de culpa por su previa sumisión a Trujillo. Participan en el magnicidio como si se tratara de un acto de contrición para recuperar la dignidad que todos ellos perdieron cuando colaboraron con el dictador. Los conspiradores de La fiesta del Chivo sienten asco de sí mismos, sienten nudos en sus estómagos, tienen pesadillas recurrentes, sienten vergüenza, tienen sus conciencias laceradas, se consideran viles a sí mismos. Los conspiradores participan en el magnicidio no solamente para redimirse a sí mismos de los crímenes y abusos en los que ellos mismos participaron, o aquellos que celebraron o que toleraron, sino también para redimirse por las humillaciones personales que sufrieron hasta que perdieran su dignidad. Viven el atentado en contra de Trujillo como una catarsis que parece redimirlos de su previa sumisión a la dictadura. Eso dicho, en la novela hay una experiencia catártica que es aun más significativa que la de los magnicidas. Se trata de la confesión de Urania - 35 años después de los hechos - en la cual ella revela a sus tías y primas que había abandonado su patria porque su padre permitió que Trujillo abusara sexualmente de ella. No todas sus parientas desean escuchar los detalles de una historia que comprometería a algunas de ellas, pero a Urania se le quita un peso de encima cuando cuenta su historia, y siente que puede empezar a hacer las paces con los hijos de los parientes cuyas conciencias morales fueron paralizadas por la dictadura. Vargas Llosa da a entender que hace falta airear los trapos sucios del régimen para que la nación pueda reconciliarse con su propio pasado.

El Paraíso en la otra esquina es también una novela cuyo tema secreto es la reconciliación de dos generaciones que sufren las conse-

\footnotetext{
${ }^{3}$ Vargas Llosa, La fiesta del Chivo, 2000, p. 187.
} 
cuencias de algunos abusos que los han afectado a lo largo de su vida. En la novela Vargas Llosa recrea las vidas de la activista política Flora Tristán y de su nieto, el pintor Paul Gauguin. Los capítulos de la novela alternan entre el recuento ficticio de 1844, el último año de la vida de Flora Tristán, cuando se embarcó en una campaña por las ciudades provinciales de Francia para conseguir adeptos a un programa político que uniría a mujeres y trabajadores en una revolución pacífica; y la recreación del período de Tahiti de Gauguin (1891-1903), el período durante el cual el pintor había tenido la esperanza de revivir un sentimiento global de búsqueda física, espiritual y religiosa en el arte moderno. La narrativa de Vargas Llosa se desplaza elegantemente de una época de la vida de sus personajes a otra, de un espacio geográfico a otro para ofrecer aperçus, observaciones y anécdotas del pasado de los dos protagonistas cuando hacen esfuerzos, en diversas partes del mundo, para realizar sus aspiraciones. En estos flash-backs Vargas Llosa le da un lugar especial al período que Flora Tristán pasó en el Perú con la familia de su padre, en Arequipa - la ciudad donde el propio Vargas Llosa nació.

En los capítulos dedicados a Flora Tristán se le presenta como una testigo y una víctima de los abusos en contra de la mujer. Las autoridades francesas no reconocen el matrimonio de su madre con un ciudadano español del virreinato peruano y por ello se confisca su propiedad cuando su esposo muere. La ley francesa no es más benévola con Flora, considerada una hija ilegítima sin el derecho legal de heredar las propiedades de su padre. Flora se casa con un hombre violento y vengativo que abusa sexualmente de ella y de sus propias hijas. Al esposo de Flora se le trata con indulgencia porque el sistema legal francés favorece los derechos de los esposos por encima de los de sus esposas, y porque los abogados y los jueces juzgan conveniente estar del lado de los acusados en casos de violaciones y de incesto.

La sexualidad transgresiva ha sido siempre una preocupación central en la narrativa de Vargas Llosa. Siempre le han interesado los temas de la violencia, la humillación asociada a la sexualidad, las relaciones íntimas que ofenden la moralidad pública aun cuando ofrecen la plenitud a sus personajes, y la sexualidad como una fuerza que puede desequilibrar los vínculos humanos. Eso dicho, a partir de ¿Quién mató a Palomino Molero? (1986) le ha preocupado a Vargas Llosa el tema del abuso sexual en la relación incestuosa. En La fiesta del Chivo, como lo vimos, trata el tema del abuso sexual de un padre aparentemente 
cariñoso que hace un regalo de la virginidad de su hija a un dictador. Tanto en La fiesta del Chivo como en El Paraíso en la otra esquina, el abuso sexual es emblemático del abuso de la mujer por una sociedad que favorece las prerrogativas de los hombres. Después de que el dictador haya abusado de ella, Urania Cabral siente el horror a cualquier encuentro sexual; y en cada capítulo en el que Flora aparece, alguien la intenta seducir, y el narrador subraya su repugnancia ante la posibilidad de cualquier encuentro íntimo con un hombre. Pero aun su propensión hacia una relación satisfactoria con una mujer tiene el obstáculo de una coartada: que su propia vida romántica sería incompatible con su compromiso político por el derecho de las mujeres. En la novela de Vargas Llosa los periplos de Flora Tristán para promover sus ideas políticas se presentan como una empresa noble, pero también como un modo de sobrellevar los abusos que sufrió en carne propia, así como su angustia como madre ante la violación de sus propias hijas por su esposo.

Como con todos sus personajes literarios inspirados en personajes históricos, la Flora Tristán de Vargas Llosa es una invención literaria. En su novela Vargas Llosa refunde escritos, cartas y hasta manuscritos de Flora Tristán para crear a su personaje. En su escritura de la novela le fue sumamente útil el texto de un diario que Flora Tristán escribió durante sus viajes por Francia para conseguir adeptos a su causa política. Tristán tenía la intención de convertir esos apuntes en un libro, pero murió antes de llevar a cabo el proyecto. La Flora Tristán que aparece en su diario es distinta de la que aparece en la novela. Vargas Llosa soslaya muchos aspectos de sus convicciones: su curiosa religiosidad, sus teorías sobre el amor como el medio necesario para conseguir la lucidez en la política, su fervor nacionalista, su actitud paternalista hacia la clase trabajadora, las categorías fisiológicas con las que consideraba inferiores por razones congénitas o biológicas, su actitud antidemocrática. Con pleno conocimiento de causa Vargas Llosa transforma ciertos textos del diario de Flora para crear una imagen que corresponde a las necesidades de su novela. Así, el tema del horror a la sexualidad de Flora Tristán, en la novela - un tema que la emparienta directamente con Urania de $L a$ fiesta del Chivo y secretamente con "Emma Zunz" de Jorge Luis Borges - es una invención de Vargas Llosa. Para ilustrar el tema veamos cómo Vargas Llosa transforma un episodio del diario de Flora Tristán. Durante una visita a un pueblo provinciano, se le aparece un individuo interesado en su causa, un individuo que desea ayudarle, aunque no 
puede comprometerse plenamente a la empresa por vicios que él mismo lamenta: "él reconoce sus vicios, los condena y sufre. Habiendo nacido bueno y bello, podría haber sido capaz de los actos más nobles, pero por sus debilidades se deja llevar [...] hacia todo tipo de vicios. Tiene el deseo sincero de servir a la clase más numerosa, comprende con gran inteligencia que en ello está la vida y el futuro de la humanidad, pero su carne lo precipita hacia los vicios y no podrá ser útil a nuestra causa"4.

En la novela Vargas Llosa transforma el episodio. El personaje aparece como un ser malsano que se da cuenta que detrás de su puritanismo Flora debe ser una mujer reprimida. Aprovecha esa intuición para azuzar los demonios de la mujer: "Flora sintió que las piernas le temblaban. Se las arregló para desviar la conversación, temerosa de que Escudié, lanzado por ese camino, le desvelara su infierno secreto, esos fondos lúbricos de su alma donde, a juzgar por sus pupilas encanalladas, debían anidar muchos demonios"5. La sexualidad atormentada de Flora es un elemento añadido, pero necesario en la novela para elaborar el tema de su activismo político como una consecuencia de los traumas que sufrió.

La sexualidad de Gauguin es también un aspecto clave de la novela. Pero para el pintor se trata de una fuente de creatividad en vez de un lastre, por lo menos a primera vista. En cualquier caso, el apogeo artístico de Gauguin coincide con el relajamiento de su apego a la moralidad burguesa, con la aceptación de su bisexualidad, y con su fascinación con otras orientaciones sexuales. Eso dicho, está dispuesto a abandonar a cualquiera con quien ha tenido una relación si esta persona representa una interferencia con su arte, ya sea Mette Gade su esposa danesa, a quien abandona para que se las arregle como pueda en Europa, o a las niñas o adolescentes que le sirven aun cuando son las madres de sus hijos. Asumiendo el punto de vista de Gauguin, la voz narrativa de la novela dice repetidamente que el amor era un obstáculo para su misión artística.

El limitado sentimiento de remordimiento que siente Gauguin cuando abandona a sus mujeres y a sus hijos podría tener una relación con el rencor que sentía hacia Aline Gauguin, su propia madre y la hija de Flora Tristán, quien lo dejó en un colegio de pensionarios para con-

\footnotetext{
${ }^{4}$ Flora Tristan, Le tour de France. Journal 1843-1844, Tomo 2, p. 145.

${ }^{5}$ Vargas Llosa, El Paraíso en la otra esquina, 2003, p. 405.
} 
vertirse en la amante secreta de un hombre de negocios vinculado al mundo del arte. El propio Vargas Llosa ha explicado que el tema central de su novela es el contraste entre dos utopías: la artística y la política; pero en su novela hay otro vínculo, quizás más profundo entre las dos historias: las consecuencias del abuso sexual. La reconciliación póstuma de Gauguin con Aline - ella también abandonada por su propia madre y víctima de abuso sexual por su padre - es un fuerte lazo entre las dos líneas narrativas de la novela. En un caso las consecuencias del abuso sexual producen el horror a la sexualidad, y en el otro caso produce un sentido exaltado de liberación sexual por un individuo casi indiferente a las consecuencias de sus acciones. En ambos casos la misión vital del personaje está vinculada con su actitud hacia la sexualidad y en ambos casos sus elecciones excluyen el amor en sus vidas personales.

En el mundo narrativo de Vargas Llosa hay antecedentes del fervor político de Flora Tristán en esos personajes comprometidos con sus utopías, como lo son Alejandro Mayta en Historia de Mayta, y Galileo Gall en La guerra del fin del mundo. Hay también antecedentes de Paul Gauguin en esos personajes determinados a cambiar un modo de vida por otro, como Saúl Zuratas en El hablador (1986) que abandona Lima para vivir con una comunidad indígena en el Amazonas. Pero Vargas Llosa trataba a sus fanáticos y excéntricos con distancia y reserva, a veces con ironía y aun con desprecio. En El Paraíso en la otra esquina presenta a sus protagonistas fanáticos con mayor indulgencia, hasta con cariño, y sin duda con menos distancia respecto a sus propias preocupaciones y a sus experiencias políticas. Se podría trazar un paralelo, por ejemplo, entre su versión ficticia del valiente pero fallido intento de Flora Tristán para lanzar un movimiento político y El pez en el agua (1993), el recuento autobiográfico de su propio intento de establecer un partido político perdurable durante la campaña política de 1990. Asimismo su representación de Gauguin resuena con la propuesta de Vargas Llosa (muy lejana a cualquier idea que el propio Gauguin haya expresado sobre el arte en sus cartas y escritos autobiográficos) según la cual la grandeza que un artista logra en un lienzo o en una novela - a veces después de muchos sacrificios personales- son dolorosos testimonios de lo que jamás se podrá lograr en el mundo de la vida cotidiana.

Como Flora Tristán en la novela, el Gauguin de Vargas Llosa es también una creación literaria. Vargas Llosa transforma tanto la biografía del pintor, como los cuadros de Gauguin a los que se refiere en la 
novela para sus fines literarios. Así, por ejemplo, el tema de la relación entre la sexualidad y la creatividad del pintor no es un tema central de los escritos autobiográficos de Gauguin. Por lo demás, la actitud de Gauguin hacia sus propias creaciones en sus cartas y otros escritos autobiográficos no coincide exactamente con la del Gauguin de Vargas Llosa. Tomemos, por ejemplo, el famoso cuadro llamado "La visión después del sermón." En sus escritos autobiográficos, Gauguin no estaba del todo contento con su técnica artística aunque se sintiera satisfecho con la promesa del cuadro:

Acabo de pintar un cuadro religioso, muy mal ejecutado, pero me interesó lo que hice y me gusta. Para mí el paisaje del cuadro y la lucha que representa entre Jacobo y el ángel solamente existe en la imaginación de estas personas que rezan después de haber escuchado un sermón 6 .

La discusión de Vargas Llosa en la novela es distinta. Su énfasis no está en la capacidad del pintor para captar una visión interna, sino en la creación de una nueva realidad que desdibuja las fronteras entre lo objetivo y lo subjetivo:

El verdadero milagro de aquel cuadro no era la aparición de esos personajes bíblicos en la mente de esas humildes campesinas. El milagro era haber conseguido en aquella tela acabar con el prosaico realismo una realidad nueva, en la que lo objetivo y lo subjetivo, lo real y lo sobrenatural, se confundían, indivisibles?

La misma discrepancia entre la visión de Gauguin con la del Gauguin de Vargas Llosa se puede advertir en la descripción de algunos de los cuadros del Tahití mencionados en la novela. Para ilustrar el punto me gustaría comentar el tratamiento ficticio del famoso cuadro "Nevermore" en la novela de Vargas Llosa. El cuadro representa a Pau'ura, la compañera adolescente de Gauguin durante su segunda y última estadía en Tahití (1895-1903). En los escritos autobiográficos de Gauguin el pintor afirma que el cuadro está mal pintado, pero no obstante sus deficiencias artísticas, siente que logró representar el deleite salvaje

${ }^{6}$ Paul Gauguin, carta a Vincent van Gogh de septiembre 22, 1888, citada en Belinda Thomson (ed.), Gauguin by Himself, 1993, p. 66.

${ }^{7}$ El Paraíso en la otra esquina, 2003, p. 286. 
y la triste resignación en su transformación del "cuervo" del poema de Edgar Alan Poe, en un pájaro local de Tahití. En su tratamiento literario del poema, Vargas Llosa hace un juicio que tiene menos que ver con el entendimiento de Gauguin de su propia obra, y más con las reflexiones recientes de Vargas Llosa sobre la impotencia del ser humano frente a las crueles fuerzas de lo irracional:

En este mundo pagano, la mujer tendida aceptaba sus límites, se sabía impotente contra las fuerzas secretas y crueles que se abaten de pronto sobre los seres humanos para destruirlos ${ }^{8}$.

Desde luego que Vargas Llosa no escribió un ensayo de historia del arte, sino una ficción en la cual, con todo conocimiento de causa, se distanció de los escritos autobiográficos de Gauguin para articular una visión artística que no es la del pintor, sino la del pintor que él inventó, una visión que se puede fácilmente compaginar con su convicción reciente de que la perfección que un artista pueda lograr en una obra de arte no se logrará jamás en la vida real. Esta idea tiene poco que ver con sus convicciones de los años 60 según las cuales la acción política podría resolver los mismos problemas que la literatura podría diagnosticar, y es también un distanciamiento de sus manifiestos de los 80 , entre ellos el ensayo liminar de La verdad de las mentiras, cuando Vargas Llosa había planteado la tesis de que la imaginación literaria, o la erótica, podría ser una compensación satisfactoria para nuestras pulsiones más irracionales.

Es interesante subrayar que a lo largo de su trayectoria literaria sus propias ficciones han a veces corregido sus ideas sobre el arte antes de que elaborara nuevas ideas sobre el arte en sus ensayos. En El Paraíso en la otra esquina, como ya lo vimos, una obra literaria convincente ya no es una compensación satisfactoria, sino un ejemplo de aquello que no se podrá realizar en el reino de este mundo; y Travesuras de la niña mala hace una propuesta equivalente con relación a la imaginación erótica que en los años 90 Vargas Llosa suponía que podría ser una compensación equivalente a la de la literatura para las insuficiencias de la vida.

Travesuras de la niña mala tiene algunos de los mismos elementos humorísticos que La tía Julia y el escribidor, pero es —con El sueno del Celta - una de sus dos novela más tristes. En esta novela Vargas

${ }^{8}$ El Paraíso en la otra esquina, 2003, pp. 203-204. 
Llosa está mucho más cerca del realismo incorruptible de sus admirados escritores rusos que de la exploración flaubertiana de los engaños que un ser humano se puede hacer a sí mismo. Ricardo Somocurcio, el protagonista de Travesuras no es un gran artista, pero es un intérprete y un traductor. Eso dicho, su vida es una vida paralela a la de Vargas Llosa. Los dos nacieron prácticamente en la misma fecha, vivieron prácticamente en los mismos países, en las mismas ciudades, y en los mismos vecindarios prácticamente al mismo tiempo; y lo hayan querido o no, sus vidas se enmarañaron íntimamente con las vicisitudes de la historia del Perú. La novela incluye un comentario de los hechos políticos e históricos del Perú desde la década de los años 50 hasta la de los 80 parando justo antes de la campaña presidencial de Vargas Llosa; y la relación principal en la novela entre Ricardo Somocurcio y una mujer misteriosa llamada la "niña mala" es una alegoría sobre la relación de Vargas Llosa con el Perú. Dentro de la tipología de personajes de Vargas Llosa, Ricardo es una posible reencarnación de Santiago Zavala — no sólo el Santiago de Conversación en La Catedral sino también el de Kathie y el hipopótamo, por su impotente conmiseración con sus conciudadanos del Perú. Y por su orgullo y sentimiento de rebeldía la niña mala es también una especie de reencarnación femenina del Jaguar de $L a$ ciudad y los perros. Como Santiago Zavala, Ricardo Somocurcio está profundamente consciente de las injusticias sociales del Perú. Observa lo que significa "ese infierno que es el Perú para los pobres", y expresa asimismo su comprensión por los "millones de campesinos bajados de la sierra, huyendo del hambre y la violencia" 10 , y como Santiago Zavala, su mejor respuesta a la situación que comprende con dolor son sus sentimientos de malestar y de frustración. Como el Jaguar, la niña mala decide hacerse cruel porque "estaba convencida que la vida era una selva donde sólo los peores saben triunfar"11. Ricardo no está comprometido con ninguna causa política, pero ayuda a un líder revolucionario latinoamericano radicado en París por haber entablado una amistad con él. Sus propias sensibilidades literarias están más cercanas a Ivan Bunin, el archiantibolchevista Premio Nobel ruso que evitó la política en sus exquisitos relatos. En la novela Ricardo es el traductor de Bunin y de Antón Chéjov, y ello es un homenaje a dos maestros de la literatura rusa

\footnotetext{
${ }^{9}$ Travesuras de la niña mala, 2006, p. 79.

${ }^{10}$ Ibídem, p. 292.

${ }^{11}$ Ibídem, p. 131.
} 
con los cuales Vargas Llosa entabló un bello diálogo en su novela para elaborar el tema de la impermanencia y precariedad de las aspiraciones y los logros humanos. Para los elementos humorísticos, Vargas Llosa se inspiró en los diálogos de los melodramas del cine mexicano de los años 1940.

Hace treinta años, con La tía Julia y el escribidor, Vargas Llosa creó la primera de una serie de novelas, entre ellas El hablador y Elogio de la madrastra, en las cuales algunos capítulos consagrados a la realidad monótona de sus personajes alternan con otros capítulos que ensayan la naturaleza compensatoria de la imaginación. Este patrón literario es un homenaje a la novela de Flaubert que Vargas Llosa ha admirado más que a cualquier otra, La tentación de San Antonio, en la cual la realidad gris del eremita alterna con escenas propulsadas por los poderes salvajes de la imaginación humana. En estas novelas Vargas Llosa quería crear un contrapunto entre la mediocridad de la vida cotidiana y las compensaciones de la imaginación; y este impulso literario coincidía con sus ensayos sobre el papel social de arte.

Vargas Llosa había querido conciliar las ideas de Karl Popper sobre las sociedades abiertas, con las doctrinas de George Bataille sobre el erotismo. Para Popper la sociedad abierta es aquella que logra separar el mundo de la realidad del mundo de la imaginación; y la sociedad cerrada no lo sabe hacer. Si para Bataille el erotismo es la sexualidad azuzada por la imaginación, para Vargas Llosa el erotismo puede compensar por las insuficiencias de la vida cotidiana, respetando el hecho de que la separación entre la realidad y la imaginación es necesaria para que no se impongan las fantasías como si fueran realidades, como sucede en las sociedades cerradas. Estas ideas estaban detrás del procedimiento narrativo más importante para Vargas Llosa en los años 80 -el que alternaba capítulos realistas con capítulos fantasiosos-, pero se ha dado un cambio importante con Travesuras que es sintomático de un cambio importante en el pensamiento de Vargas Llosa respecto a la literatura. En Travesuras de la niña mala, la línea que separaba la monótona existencia de la imaginación erótica no solamente se ha desdibujado, sino que ha desaparecido. La protagonista de la novela, la niña mala, es simultáneamente una presencia real para el argumento de la novela como una fantasía erótica y una creación literaria. Aparece y reaparece en la vida de Ricardo en las circunstancias más extraordinarias, y no puede diferenciar, como el narrador lo dice, "el mundo en que vivía de aquel 
en el que decía vivir" ${ }^{2}$. Cada vez que reaparece en el mundo monótono de Ricardo Somocurcio lo hace como si fuera una mujer de carne y hueso, pero es también una fantasía, una creación literaria que ha ingresado en el mundo de los vivientes, como en "La continuidad de los parques", esa brevísima obra maestra de Julio Cortázar en la cual el mundo de la ficción y el mundo cotidiano se conectan como los dos lados continuos de una tira de amebas. Como uno de los mayores maestros de la narrativa de nuestro tiempo, Vargas Llosa tiene todo el oficio que le hace falta para presentar a sus personajes con el suficiente número de ambigüedades, misterios, y elipsis, para que cada capítulo pueda ser leído simultáneamente como una fantasía o como una realidad. Como si se tratara de una variante ingeniosa de un procedimiento literario del Gabriel García Márquez de Cien años de soledad, cada capítulo de la novela avanza cronológicamente según la historia del Perú desde los años 50 hasta los finales de los 80, según también la cronología de la vida de Ricardo Somocurcio; pero el tiempo parece detenerse como si se estuviera repitiendo una misma historia, como si se tratara de una variación sobre el mismo tema, como si se tratara de la repetición de una obsesión: en cada capítulo la niña mala aparece en la vida de Ricardo, en cada capítulo ella es el objeto de sus deseos eróticos; en cada capítulo lo erótico se contrasta con la muerte o con la agonía de algún personaje. Como en una composición musical en la cual un tema ligero se contrasta con otro más hondo, el tema ligero no resiste la repetición; en la novela la repetición de lo risueño se debilita ante el realismo de la mortalidad. La gran revelación de la novela es el pasado de la niña mala, un pasado duro que ella ha reprimido. Esta revelación ofrece, quizás, una de las claves más pertinentes para aclarar toda la obra literaria de Vargas Llosa.

Durante muchos años Vargas Llosa ha argumentado que la imaginación literaria es una compensación por las insuficiencias de la vida. Su personaje la "niña mala" es un contraejemplo de su propia doctrina. La clave de la novela está posiblemente en un comentario de Ricardo, cuando descubre los orígenes peruanos de la mujer, cuando aprende que ella fue la hija de inmigrantes andinos a Lima que vivieron en una pobreza sórdida: "la imaginaba de pequeñita, en la promiscuidad y la mugre de esas casuchas contrahechas de las orillas del Rímac"13. En

${ }^{12}$ Travesuras de la niña mala, 2006, p. 175.

13 Ibídem, p. 322. 
la novela, la "niña mala" sufre un trauma severo asociado a la violencia sexual, y el narrador comprende por qué ella necesita escapar a un mundo de la ficción: "Vivir en esa ficción le daba razones para sentirse más segura, menos amenazada, que vivir en la verdad. Para todo el mundo es más difícil vivir en la verdad que en la mentira. Pero más para alguien en su situación. Le va a costar mucho acostumbrarse a la verdad"14. El comentario se explaya en la novela por un especialista de tortura y trauma: "Pero ella, y todos quienes viven buena parte de su vida encerrados en fantasías que se construyen para abolir la verdadera vida, saben y no saben lo que están haciendo. La frontera se les eclipsa por períodos, y luego reaparece" 15 .

En sus meditaciones sobre José María Arguedas, Vargas Llosa ha insistido que las tensiones más desgarradoras en las novelas de Arguedas tienen su origen en las experiencias infantiles de su compatriota. La imaginación literaria de Arguedas, en la cual la sexualidad es invariablemente presentada como un pecado, y su voz narrativa que busca lo que él mismo llamó "el fuego purificador", tiene, según Vargas Llosa, su fuente en algunas experiencias traumáticas que Arguedas sufrió de niño. La imaginación literaria de Arguedas es presentada por Vargas Llosa como una compensación por su sentimiento de ultraje, más profundo que sus convicciones políticas y sus contradicciones antropológicas.

Con Travesuras de la niña mala Vargas Llosa ha cerrado un ciclo. Siempre se ha referido, sin especificar los detalles $-\mathrm{y}$ no hace falta que lo haga-, que hubo experiencias traumáticas que lo llevaron a ser un escritor de ficciones. Durante muchos años ha insistido en las peligrosas fuerzas irracionales que conllevan a la necesidad de inventar realidades alternativas: pero en esta novela las compensaciones de la imaginación literaria y de la experiencia erótica resultan insuficientes, y dichas insuficiencias son conmensurables con un grado de sufrimiento que las hace palidecer porque son demasiado reales. Esta novela es tan explícitamente y gráficamente sexual como cualquier otra de Vargas Llosa, pero en ella la sexualidad está matizada por el dolor, la tristeza y los sufrimientos del pasado; y en la medida que deja de ser el motor principal de la relación entre sus protagonistas Vargas Llosa empieza a tratar un tema que no había tratado antes: el tema del amor; o la constatación de que en algún momento del pasado algo malogró la posibilidad

${ }^{14}$ Travesuras de la niña mala, 2006, p. 26.

15 Ibídem, p. 268. 
del amor. Ello conlleva al duro pero maduro y honesto reconocimiento de que las compensaciones de la literatura y del erotismo pueden ser subterfugios para proteger a un ser dañado; para evitarle otras emociones más dolorosas, pero quizás también más redentoras. Como en los relatos de Antón Chéjov, que Ricardo Somocurcio tradujo, las verdaderas complejidades de la vida nunca se resuelven con facilidad, y no se comprenden sin el doloroso realismo del amor.

Desde este punto de vista la última novela de Vargas Llosa, El sueño del celta, es una versión trágica del tema que elabora en Travesuras de la niña mala, porque en El sueño del celta hay también un viaje que va de la utopía a una confrontación con la realidad, pero a diferencia de Las travesuras, que termina con la posibilidad del amor, El sueño del celta termina con un sentimiento de resignación, con la aceptación de la muerte por un personaje que se ha sentido defraudado por la vida y defraudado en el amor.

El protagonista de El sueño del celta había sufrido muchos cambios y mudanzas en su vida, pero con cada cambio y con cada mudanza vienen nuevas decepciones. Tiene decepciones en su vida como diplomático cuando se da cuenta de los abusos humanos en los lugares donde representaba a Inglaterra, tiene decepciones en sus actividades a favor de los derechos humanos en el Congo y en el Amazonas cuando se da cuenta de que las labores de los que luchan por los derechos humanos pueden ser manipuladas por los políticos, tiene decepciones cuando decide luchar por la liberación de Irlanda, y tiene decepciones también en su vida amorosa, e incluso en su intento de convertirse al catolicismo. Al final de su vida, cuando ha sido condenado a morir, el personaje se resigna, no protesta, no recuerda sus labores como defensor de los derechos humanos, no desea que lo acompañen los curas, y su última palabra es un susurro, la palabra "Irlanda" que pronuncia sin el fervor nacionalista que hasta hace poco lo había caracterizado. Las últimas novelas de Vargas Llosa comparten el sentimiento de que las fuentes de la insatisfacción humana no se resolverán ni con la rebelión ni con la fantasía, son novelas cuyo tema central es la reconciliación humana, son novelas con añoranzas espirituales, y con una frágil apertura hacia el amor. 


\section{REFERENCIAS}

Tristan, Flora. Le tour de France. Journal 1843-1844. Tomo 2. Paris: Indigo \& Coté-femmes éditions.

Vargas Llosa, Mario. La fiesta del Chivo. Madrid: Alfaguara, 2000.

- Travesuras de la niña mala. Madrid: Alfaguara, 2006.

- El Paraíso en la otra esquina. Santillana Ediciones, 2003.

"Günter Grass en la picota". El País, agosto 27, 2006. - El sueño del celta. Madrid: Alfaguara, 2010.

Thomson, Belinda (ed.). Gauguin by Himself. London: Little Brown and Company, 1993. 